\title{
BENEFITS OF MANAGEMENT GAMES IN DISPLAYS PERFORMANCE STUDENT AT ILEARNING EDUCATION
}

\author{
Desy Apriani: ${ }^{* 1)}$, Eka Purnama Harahap ${ }^{2)}$, Paramitha Kusuma Wardhani ${ }^{3)}$ \\ 1,2,3,4 Program Studi Sistem Informasi, Universitas Raharja \\ *1desv@ raharia.info, ${ }^{*}$ ekapurnamaharahap@ raharja.info, ${ }_{2}^{3}$ paramitha.kusuma@ raharja.info
}

\begin{abstract}
The development of learning in education has now increased. As time goes on, technology has grown rapidly. With the development of technology today can help the learning process. One example of technological advancement in education is E-Learning. E-Learning provides the convenience of lecturers and students in distance learning so that learning runs effectively and efficiently. In an effort to improve the quality of education in Indonesia, Raharja University has implemented an online learning system called iLearning. But iLearning's online learning system has not been the maximum, there are some students who have not been active in the classroom as the lecture took place and there are still students who are late working on the assignment given. To improve the performance of students while in the classroom and to perform timely assignments lecturers apply a method of gamification. Students will earn points when working on an assignment that has been given by the lecturer. The earning points are listed on the iDu Dashboard in order to provide motivation for students to do other tasks and compete with classmates. The methods used to address these problems include SWOT analysis methods, Literature Review, and Unified Modelling Language (UML) as a modeling design. This research aims to improve student performance in the process of teaching and learning activities.
\end{abstract}

Keywords - iLearning, Gamification, Education

\section{Introduction}

The advancement of information technology always develops very rapidly and spreads almost in all areas. The development of technology nowadays facilitates human activities in doing various things. All things can be done with the help of technology. Education today has also collaborated with the help of technology. In the development of this technology, the educational world also experienced considerable improvement. In LAW No. 12 of 2012 discussing higher education, the Government gave special attention to improving the quality of higher education in Indonesia.

As an example of the technological developments in education is online learning or elearning. E-Learning technology can be utilized to support the learning process for homeschool organizers (Winarno \& Setiawan, 2013). Today's online learning no longer requires students to come to campus. It really helps students who want to attend the lecture but are hindered by time. According to Anggoro (2005) The term e-learning is a change in the process of teaching learning into a more digital form by utilizing existing technologies such as the Internet (Anggoro, 2005). Raharja University as a technologyengaged campus, has been using an online learning system. The online learning in the University of Raharja is iLearning, with the intention to provide the best quality in education in Indonesia. According to Untung Rahardja (2011) iLearning is a new thing in the online learning system in the world of education by Method 4B (study, work, play, Pray) (Rahardja, et al 2011). The main thing in online learning systems or iLearning is the 
teaching materials that students will get. Just like conventional learning in general, online learning or iLearning also has a curriculum. Along with the progress and development of the current technology, Universitas Raharja uses a new device as a learning facility that is the iPad. The iPad facility provided to students can be used at home. This can make it easy for students to download materials easily and quickly. Although iLearning is included in the online learning system, the teaching and learning process remains in the classroom, so students are required to attend classes in the classroom.

The learning system in the iLearning class is now running well but not maximally, there are still some students missing in the assignment, that is because there are still some students who delay or neglect to work on assignment. To improve the performance and give a sense of responsibility to the students with the duties given, lecturers apply a method of management gamification. Gamification is a process that provides a gaming experience that creates value thoroughly (Zichermann \& Cunningham, 2011). According to Glover Gamification can provide motivation to students to follow the learning process (Glover, 2013). Gamification aims to improve user's sense of association with a software (Huotari \& Hamari, 2012). This method of gamification aims to improve the performance of students in order to keep the spirit of working on the assignment that the lecturers are given in a timely manner. In this management gamification method lecturers will give a reward. The Rewards are the points that the student will earn after working on assignment. Every student who has done an assignment on time will earn points. The points in the management Gamification method are imperative, the points given will trigger the student to complete the assignment (Chrons \& Sundell 2011. The points that students have earned will be listed on the iDu dashboard. The Dashboard or viewboard commonly known to Raharja University is an application system that can provide information in the form of panels that are important to the leader in order to control its organization on target, purpose, vision and mission (Rahardja, et al, 2016). In the iDu dashboard there is a sequence of student names and the number of points earned. The number of points and levels in the dashboard aims to increase the motivation of the students in doing the task according to the specified time. Make students more sportsmanship and competitive with their classmates to race to earn the most points. The points that the student has earned can be exchanged for the missing assignment. Points redemption can be made on the conditions specified by the lecturer. In general, points redemption will be done at the end of semester.

By applying this management gamification method provides motivation for students to improve their performance in lecturing activities or to work on assignment timely or before the due date limit. In the application of management gamification there is a concept that aims to make students not get bored and create a pleasant atmosphere when lecturing activities in the classroom.

\section{Research Methods}

\section{iLearning}

iLearning (Integrated Learning) is related to the aspects of life, such as studying, playing, working, and praying (Rossing et al, 2012). iLearning is a merger of natural resources in implementing Tri Dharma colleges by using an iPad device that aims to support the learning process (Rahardja et al, 2014). The iLearning method is a recent breakthrough that combines learning, working, praying, and playing. The existence of the iLearning system makes students more creative and critical thinking. iLearning is a new innovation in the online learning system applied by Raharja University. To provide convenience to 
all students of Universitas Raharja. With iLearning, students can do all teaching and learning activities using an iPad device, Laptop, computer, and others. Make students have an association in studying. Material submission is also easier and makes students feel unsaturated in the course of learning in the classroom.

\subsection{Methodology}

In carrying out this research uses several methodologies, namely a). Literature Review of this research sourced from literature related reviews, obtained through various sources of books and journals that have an association with this research as a reference,

b). SWOT analysis is comparative between the external factors opportunity (opportunities) and the threat (Treats) with the internal factor strengths (Strengths) and weaknesses (Weakness),

c). The design concept method uses the Unified Model Language (UML) for the design concept to be created. UML is a trustworthy tool in the world of developing an objectoriented system (Munawar, 2005).

\subsubsection{Literature Review}

Literature Review is a breakdown of theories that can be used as a reference and can be obtained from various sources of books, journals and the Internet. The Literature review is an essence of the results of a previous invention used as a reference in the research of a project (Zainal, 2007). There are 4 (four) research from previous sources that have correlation with the research to be discussed, namely:

1. Research conducted by Qurotul Aini, Hani Dewi Ariessanti and holy book in 2017 from STMIK Raharja under the title "Application of Gamification-based iDu Plus adoption as a medium of remote learning in college" This study discusses Gamification in support of iLearning learning systems. The system is built for the purpose of the iDu iLearning Plus learning, so that the lecture activities can run effectively and efficiently. Students can conduct lectures at home without having to come to campus. Students can do lectures anywhere with the internet and media devices such as iPad, Laptop and other students can already do lectures (Ariessanti \& Aini, 2017).

2. Research conducted by Eka Ismantohadi, Lukito Edi Nugroho and Sri Suning Kusumawardani in 2015 from Gadjah Mada University titled "E-Learning system prototype with a VARK learning style approach (case: Indramayu Polytechnic" This research discusses the various characteristics of learning styles in learners. To know the characteristics of learners are conducted approaches with Visual, Audio, Read and Kinesthetic (VARK). Using a prototype E-learning system The VARK approach can identify appropriate learning styles for students (Ismantohadi et al, 2015).

3. Research conducted by Untung Rahardja, Qurotul Aini, Hani Dewi Ariessanti and Alfiah Khoirunisa in 2018 from STMIK Raharja with the title "Effect of gamification on iLearning education" in improving student motivation learning "This study discusses the implementation of a gamification method in an iLearning Education so that students can be motivated to conduct lectures. The Gamification method assists students in earning points, so that students become more active and passionate about the task given by the lecturer (Rahardja et al, 2018).

4. Research conducted by Heni Jusuf in 2016 from National University titled "Use of gamification in the learning process" This study discusses factors that are the determinant of the motivation in learning. In applying a gamification does not have 
to create a game to make learning fun. Building engagement with students will make learning a more enjoyable way (Jusuf, 2016)

\subsection{SWOT Analysis}

Besides the literature method of review and activity diagram, Next is the method of SWOT analysis. Freddy Rangkuti (2006) SWOT analysis is an identification of a variety of factors that are systematically used to formulate strategies (Rangkuti, 1998). SWOT Analysis is a multidimensional tool used for strategy analysis (Alfeno et al, 2019). This analysis is used to optimize strength and opportunity, and can minimize threats (threats) and weaknesses (weakness).

Table. 1 SWOT Analysis

\begin{tabular}{|l|l|}
\hline $\begin{array}{l}\text { Strength (S) } \\
\text { Kekuatan }\end{array}$ & $\begin{array}{l}\text { Weakness (W) } \\
\text { Kelemahan }\end{array}$ \\
\hline $\begin{array}{l}\text { 1. Tersedianya Sumber } \\
\text { dengan teknologi informasi }\end{array}$ & $\begin{array}{l}\text { 1. Sumber Daya Manusia } \\
\text { yang masih asing dengan } \\
\text { teknologi informasi }\end{array}$ \\
$\begin{array}{l}\text { 2. Pembelajaran menjadi } \\
\text { lebih efektif dan } \\
\text { menyenangkan }\end{array}$ & $\begin{array}{l}\text { 2. Dalam mengerjakan } \\
\text { tugas mahasiswa masih } \\
\text { bergantung pada internet } \\
\text { (copy paste) }\end{array}$ \\
$\begin{array}{l}\text { 3. Materi pembelajaran } \\
\text { dapat diunduh dimana saja } \\
\text { dan kapan saja }\end{array}$ & $\begin{array}{l}\text { 3. Tidak semua tempat } \\
\text { mendapatkan koneksi } \\
\text { internet }\end{array}$ \\
\hline $\begin{array}{l}\text { Opportunities (O) } \\
\text { Peluang }\end{array}$ & $\begin{array}{l}\text { Threats (T) } \\
\text { Ancaman }\end{array}$ \\
\hline $\begin{array}{l}\text { 1. Lingkungan pendidikan } \\
\text { yang terjangkau dengan } \\
\text { koneksi internet } \\
\text { mendikangangang }\end{array}$ & $\begin{array}{l}\text { 1. Perubahan tekologi } \\
\text { informasi ssat ini yang } \\
\text { begitu cepat tdak dapat } \\
\text { menjamin pembelajaran } \\
\text { online iLearning akan tetap } \\
\text { menjadi pembelajaran } \\
\text { online yang efektif }\end{array}$ \\
\hline
\end{tabular}

\section{Results And Discussion}

\subsection{Problems}

In research made by the authors, there are certainly problems experienced. Each student will get the assignment given by the lecturer, but in this case there are still some students who neglect to work on the assignment in a timely manner. The result of student negligence may harm the student because the student will get the 0 or missing value on the iDu automatically. With the method of management gamification in learning, it can increase the motivation of students to work on the assignment that has been given.

\subsection{Problem Solving}

The next method is the concept method of design activity diagram. According to Sri Dharwiyanti et al, the activity diagram illustrates the sharing of activity in a system that is in the planning phase (Dharwiyanti \& Wahono, 2003). The activity diagram is an activity 
that is formed to perform an operation and can be used for other activities (Widodo \& Handayanto, 2013).

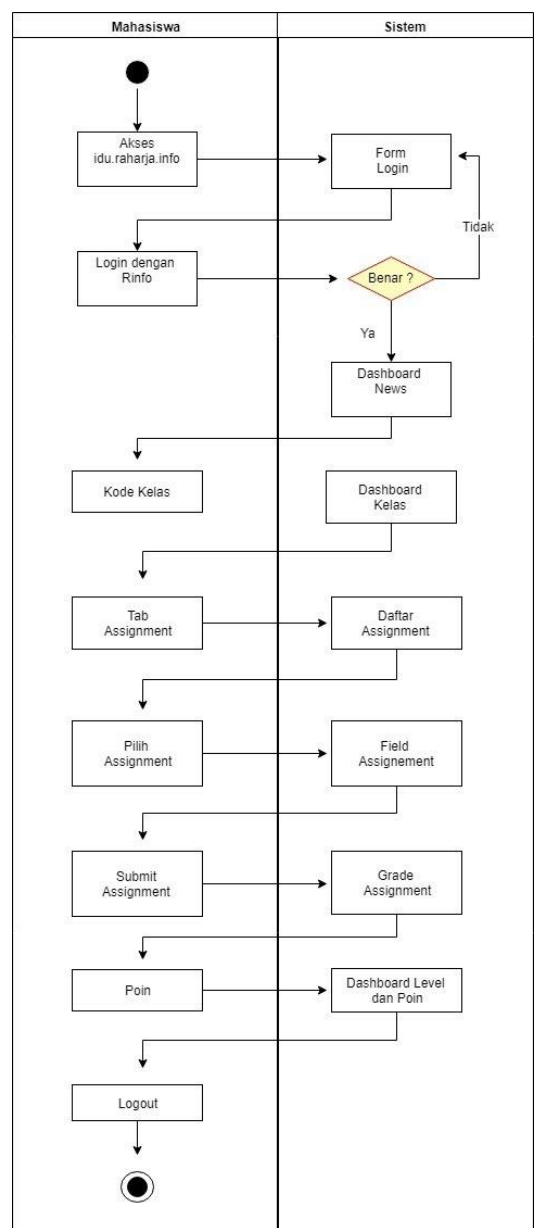

Figure 1. Activity Diagram System

Activity diagram on picture I The student process is doing assignment on the website idu.raharja.info the currently run Raharja University, consisting of:

1. There is 1 initial node

2. There is 1 final node

3. There are 1 decision

4. There are 2 swimline (student, System)

5. There are 15 actions describing the storyline activity diagram

\subsection{Research Implementation}

Based on the research above, iLearning learning at Raharja University is now good. On iLearning learning has applied a management gamification method to support the learning process. The mangement Gamification method motivates students to be more active and passionate about learning in the classroom. This research demonstrates a new study with the management gamification method of getting a good response from students. The advantage of this method of management gamification can motivate students in the learning process and to compete sporvely with classmates because the task that has been done by the students will get points from the task, in this case it triggers the student spirit to work on the task on time and earn more points. 


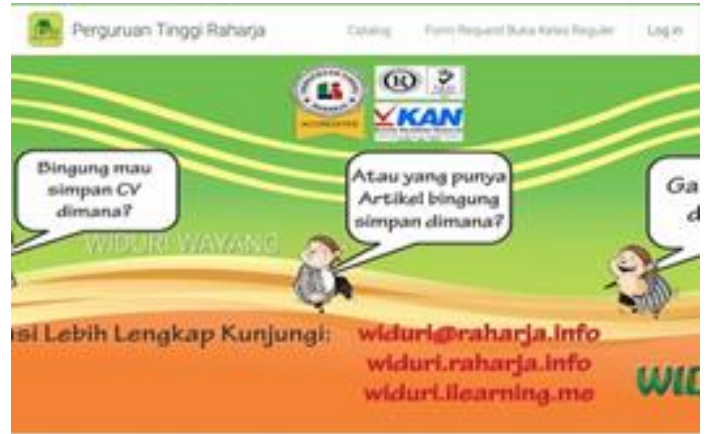

Figure 2. Main Page view Login on iDu

Figure 2. Initial display on an iLearning Education. The first step is to login with SSO (Single Sign On) via Rinfo. After successful login, the user will be taken to the news iDu (iLearning Education) page.

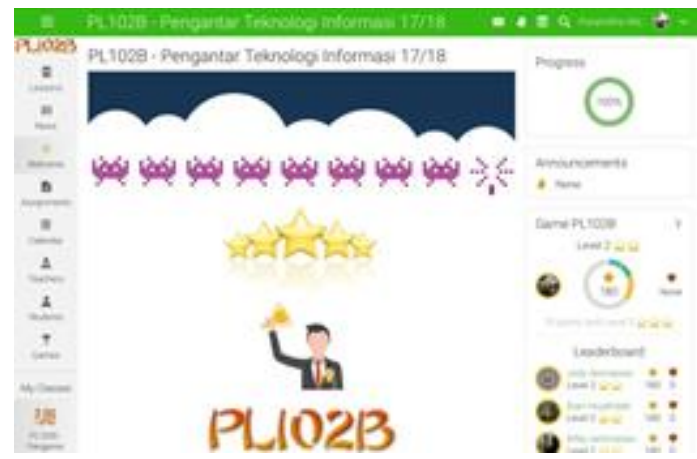

Figure 3. Class View on iDu

Figure 3. In the Class View. There are several tabs like, Welcome tab, Lesson tab, News tab, Assignment tab, Calendar tab, Teachers tab, Students tab, and Games tab.

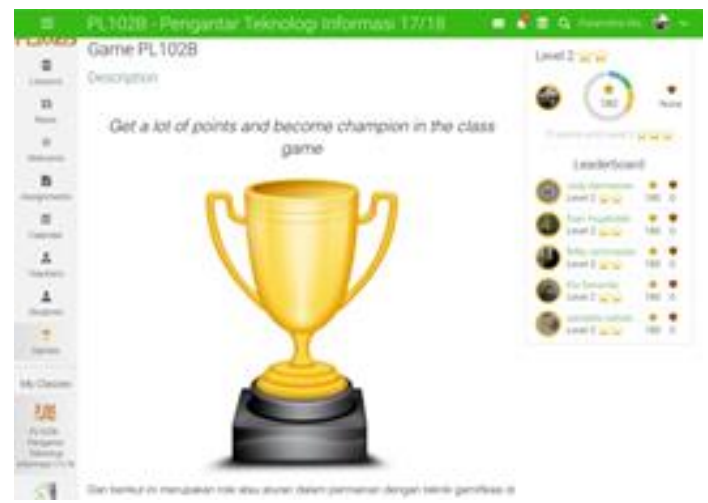

Figure 4. Display games on the iDu class

Figure 4. The Games menu displays on the iLearning Education class to see what games the lecturers provide. 


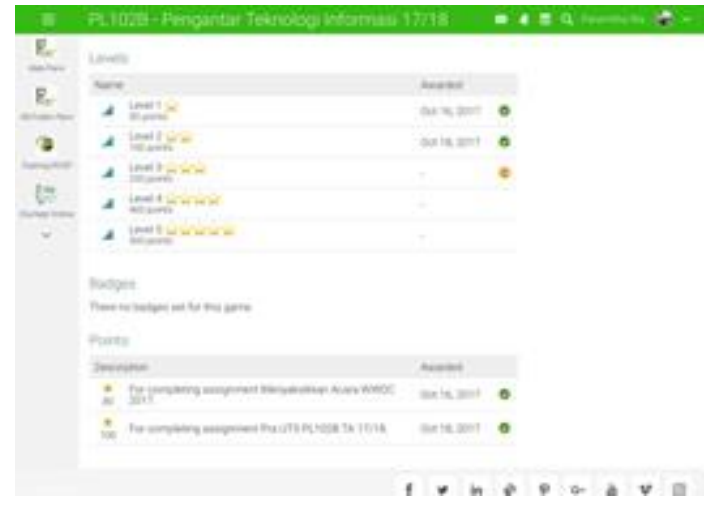

Figure 5. Point and level display on iDu

Figure 5. Point and level display to display the number of points to be earned and the assignment to be performed by the student.

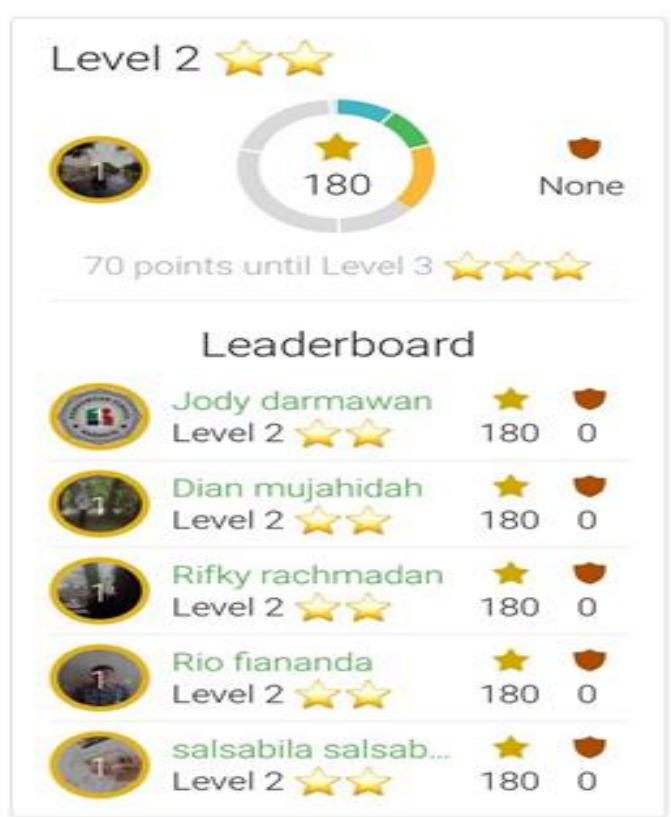

Figure 6. Dashboard ranking View

Figure 6. View of the ranking to see students who have achieved achievements from all students among other students.

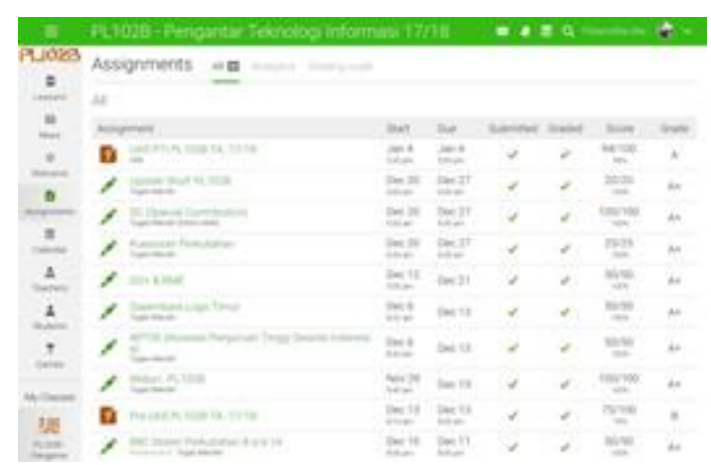

Figure 7. Class View on iDu 
Figure 7. Class display in iDu there are several tasks that have been given lecturers, and students can know the tasks that have been done and that have not been done, students who have not done the task or missing are not able to work on the task and the missing task automatically gets the value 0 .

\section{Conclusion}

Currently, iLearning learning system is good enough. The iLearning learning system can facilitate students in the learning process. With the existence of iPad devices, laptops and others so that the learning process can run well. Applying the method of management gamification on learning can increase the motivation of students to work on the assignment given by the lecturers in a timely manner so that students are not saturated during the learning process. Students will earn rewards in the form of points if they have done assignments on time. The points earned by the student will be listed on the iDu dashboard. On the iDu dashboard, there is a list of student names earning points so students will be motivated to work on their assignment on time and compete with their classmates to earn the most points.

\section{Suggested}

Based on the research above, the authors suggest that the method of management gamification in learning is improved so as to trigger the student spirit in working on the assignment that has been given by the lecturer.

\section{References}

Alfeno, S., Haris, H., \& Pamungkas, A. B. (2019). "Implementasi E-Learning Sebagai Penunjang Standarisasi K-13 Berbasis Web Dalam Peningkatan Kompetensi Pembelajaran Pada SMAN 8 Kabupaten Tangerang," Jurnal Maklumatika, vol. 5, no. 2.

Anggoro, W. B. (2005). "Penerapan e-Learning sebagai Langkah Universitas Islam Indonesia Meningkatkan Kualitas dan Efektivitas Penyelenggaraan Pendidikan Konvensional," Lomba Karya Tulis Ilmiah. Yogyakarta: Universitas Islam Indonesia.

Ariessanti, H. D., \& Aini, Q. (2017). "Penerapan iDu iLearning Plus berbasis Gamification Sebagai Media Pembelajaran Jarak Jauh pada Perguruan Tinggi," Technomedia Journal, vol. 1, no. 2, pp. 37-49.

Chrons, O., \& Sundell, S. (2011). "Digitalkoot: Making Old Archives Accessible Using Crowdsourcing, workshop at HCOMP August 2011."

Dharwiyanti, S., \& Wahono, R. S. (2003). "Pengantar Unified Modeling Language (UML)," Ilmu Komputer, pp. 1-13, 2003.

Glover, I. (2013). "Play as you learn: gamification as a technique for motivating learners," in Edmedia+ innovate learning, pp. 1999-2008.

Huotari, K., \& Hamari, J. (2012). "Defining gamification: a service marketing perspective," in Proceeding of the 16th international academic MindTrek conference, pp. 17-22. 
Ismantohadi, E., Nugroho, L. E., \& Kusumawardani, S. S. (2015). "Prototipe Sistem ELearning dengan Pendekatan Gaya Belajar VARK (Kasus: Politeknik Indramayu)," Jurnal Nasional Teknik Elektro dan Teknologi Informasi (JNTETI), vol. 4, no. 3, pp. 147-156.

Jusuf, H. (2016). "Penggunaan Gamifikasi dalam Proses Pembelajaran," Jurnal TICom, vol. 4 , no. 3 , p. 92772.

Munawar, A. (2005). “Pemodelan Visual Dengan UML,” Jkt. Graha Ilmu.

Rahardja, U., Aini, Q., Ariessanti, H. D., \& Khoirunisa, A. (2018). "Pengaruh Gamifikasi pada iDu (iLearning Education) dalam Meningkatkan Motivasi Belajar Mahasiswa," NJCA (Nusantara Journal of Computers and Its Applications), vol. 3, no. 2, pp. 120-124.

Rahardja, U., Desrianti, D. I., \& Mawadah, S. (2011). "Ibooks Standardisation And Good Practice For Effective Education Methods Insupport Of Ilearning," Creative Communication and Innovative Technology Journal, vol. 5, no. 1, pp. 70-91.

Rahardja, U., Pratama, D., \& Susanti, E. (2016). "Implementasi Viewboard Dalam Mendukung Penyebaran Informasi Dengan Penyajian Artificial Informatics Pada Perguruan Tinggi," Creative Communication and Innovative Technology Journal, vol. 9, no. 3, pp. 251-257.

Rangkuti, F. (1998). Analisis SWOT teknik membedah kasus bisnis. Gramedia Pustaka Utama.

Rossing, J. P., Miller, W., Cecil, A. K., \& Stamper, S. E. (2012). "iLearning: The future of higher education? Student perceptions on learning with mobile tablets,".

Winarno, W., \& Setiawan, J. (2013). "Penerapan Sistem E-Learning pada Komunitas Pendidikan Sekolah Rumah (Home Schooling)," Ultima InfoSys: Jurnal Ilmu Sistem Informasi, vol. 4, no. 1, pp. 45-51,.

Widodo, P. P. \& Handayanto, R. T. (2013) "Herlawati. 2011," Menggunakan UML. Bandung: Informatika.

Zainal, A. (2007). "Metodologi Penelitian pada Bidang Ilmu Komputer dan Teknologi Informasi; Konsep, Teknik, dan Aplikasi." Fakultas Ilmu Komputer Universitas Indonesia.

Zichermann, G., \& Cunningham, C. (2011). Gamification by design: Implementing game mechanics in web and mobile apps. "O'Reilly Media, Inc.,".

Yusup, M., \& Aini, Q. (2014). “Aplikasi Campus Learning System iOU (integrated Online Ujian) Dalam Mendukung Kegiatan iLearning Education (iDu) Pada Perguruan Tinggi," Creative Communication and Innovative Technology Journal, vol. 7, no. 3, pp. 368-383. 